\title{
Comments
}

\section{BEYOND THE BAIL SYSTEM: A PROPOSAL FOR PRETRIAL RELEASE IN CALIFORNIA}

\author{
Despite the Legislature's attempts to develop a fair and effective \\ system of pretrial release, ${ }^{1}$ California retains an anachronistic system \\ of bail ${ }^{2}$ and own-recognizance. ${ }^{3}$ Although some critics have character- \\ ized the California pretrial release system as functioning "fairly well"4 $\mathrm{m}$
}

1. See Comment, Tinkering with the California Bail System, 56 CALIr. L. REv. 1134 (1968) [hereinafter cited as Comment, California Bail System].

2. Cal. Penal Code $\S \S 1268-1320$ (West Supp. 1968).

3. Id. $\$ \S 1318-1320$. An accused released on his own recognizance refers to release without bail on the promise of the accused to appear. The California Legislature adopted the own recognizance release procedure in 1959. Id.

4. Comment, California Bail System, supra note 1, at 1177. The author based this statement on surveys conducted in San Mateo, San Joaquin, Fresno, and Kings Counties which showed that the rates of release in those areas were 66 percent of the total number of accused arrested.

Several criticisms can be made of this conclusion. The effectiveness of current pretrial release procedure is determined by applying a "victim" test. A "victim" of the bail system is one who is unable to secure release within 24 hours because of inability to meet its monetary conditions. However, the definition does not include transients or meligibles as "victims," or those accused who either had the charges dropped against them or were sentenced within 48 hours as potential "victims". The transients should be included as "victims" because they, but for their inability to achieve bail or secure release on their own recognizance, would have been released. "Ineligibles" are those who are detained on "no bail" warrants, or with parole or armed service holds. The "ineligibles" not charged with capital crimes should be counted as "victims" because judges have discretion to deny bail only if the accused has been charged with an offense punishable by death when proof of his guilt is evident or the presumption great. CAL. Penal Code $\$ 1270$ (West Supp. 1968). See text accompanying note 59 infra. There is no statutory authorization for denying bail to other members of the "inehigibles" class. Those accused who had the charges dropped against them or were sentenced within 48 hours should be regarded as potential victims since it is likely that some portion of both these groups would have been "victims" if the charges had not been dropped against them or they were not sentenced shortly after arrest Assuming that 28 percent of these groups, the original percentage detained under the "victim" test, plus the transients and noncapital "ineligible" offenders, would not have made bail or have been released on their own recognizance, the "victim" figure rises to 39 percent.

The number of accused who would have been unable to make bail or would not have been eligible for release on their own recognizances would almost certainly be higher if the study had been conducted in predominantly urban, rather than rural or suburban jails. The number of Negro felony defendants convicted in Fresno, Kings, and San Joaquin Counties in 1966 was 18.6 percent, 20 percent, and 20.1 percent respectively of total felony convictions in those counties. 1966 CaL. Bureau CrIM. 
terms of rates of release, it unnecessarily disadvantages a significant number of individuals. ${ }^{5}$ Analysis of rates of release under current law puts the cart before the horse: Before one seeks to determine how effeetive the system is, and what modifications are necessary to make it nore effective, one should ask whether the system is needed at all. The purposes of this Comment are to deinonstrate that the present pretrial release procedures impose an excessive social cost on inany of those who are arrested; and that California could and should adopt a system of pretrial release that would, with certain qualifications, release all those accused of crimes without requiring the posting of security or the showing of community ties. ${ }^{8}$ This Comment proposes a statutory model for such a pretrial release system, synthesizing many of the best features of pretrial release systems currently in use in the United States.

This Comment assumes, first, that it is unfair and unreasonable to incarcerate many individuals in order to keep a few from absconding; and second, that it is necessary to develop a more adequate pretrial release systen in order to strike a fair balance between the state's interest in seeing justice done and the individual's interest in securing his pretrial freedom. Examining the balance that exists in the current pretrial release system and investigating a proposed alternative that maximizes release and at the same time inaintains current low rates of default may help in achieving the desired fair balance.

Stat. ANn. ReP. 118. The percentages for urban San Francisco and Alameda Counties were 42.2 percent and 39.3 percent respectively. Id. Given these figures, it is reasonable to assume that a greater percentage of total arrests are Negroes in urban areas. Negroes are less able to achieve bail or own-recognizance release. See REPORT of THE NATIONAL ADVISORY COMM'N ON CTVI Disorders passim (1968) [heremafter cited as CTVIL DISORDERS].

5. See, e g., Ford Foundation \& County of Alameda, Pre-Trial Release IN OAKLAND, CaIIfornia 28 (1967) [hereinafter cited as OAK. REP.]. The Oakland PreTrial Release Project found that 64 and 39 percent respectively of felony and misdemeanor accused remained in jail until adjudication. Id.

6. Community ties refers to those factors, such as length of residence in the community, employment history, and contacts with family which a judge uses in assessing the risk of releasing an accused on his own recognizance. See McCarthy \& Wald, The District of Columbia Bail Project: An Illustration of Experimentation and a Brief for Change, 53 GEo. L.J. 675, 704-07 (1965) [hereinafter cited as McCarthy \& Wald, D.C. Bail Project]; Ares, Rankin, \& Sturz, The Manhattan Bail Project: An Interim Report on the Use of Pre-Trial Parole, 38 N.Y.U.L. REV., 67, 73 (1963) [hereinafter cited as Ares, Rankin, \& Sturz, Manhattan Bail Study].

The proposed pretrial release statute, see Part II infra, does not eliminate coinmunity ties as a device for mimimizing the risk of willful nonappearance. The accused with ties to the community is more bikely to appear than an accused without ties. The difficulty with making community ties an exclusive standard, however, is that inany accused cannot qualify for release, see note 37 infra and accompanying text. Under the proposed statute, the court can utilize commumity ties whenever they exist, see text accompanying note 77 infra, but the absence of such ties does not preclude release. 


\section{A CRITIQUE OF THE CALIFORNIA PRETRIAL RELEASE SYSTEM}

\section{A. The Accused Will Appear Without Pecuniary Compulsion}

The premise underlying the bail system-that the accused criminal will not appear without pecuniary compulsion-is erroneous. Release systems which do not rely on depositing property with the court have equally low default rates. Most defaults under bail and other release systems are merely technical, not intentional, and the fcar of recapture and subsequent imposition of additional penalties seems to be the major deterrent to willful defaults.

The primary purpose of bail in California is to insure the presence of the accused in court at the required time. ${ }^{7}$ Implicit in this purpose is

7. Cal. Penal Code $\$ 1269$ (West 1966); In re Brumback, 46 Cal. 2d 810, 813, 299 P.2d 217, 219 (1956). There is some confusion as to whether insuring the presence of the accused is the sole or the primary purpose of bail in California. Compare In re Brumback, supra (primary purpose) with Ex parte Duncan, 54 Cal. 75, 77 (1879) (sole purpose); see In re Newbern, 55 Cal. 2d 500, 504, 360 P.2d 43, 45, 11 Cal. Rptr. 547, 549 (1961) (only permissible purpose). The California courts have used both words and on some occasions neither. See, e.g., People v. Wilcox, 53 Cal. 2d 651, 349 P.2d 522, 2 Cal. Rptr. 754 (1960) (insuring the presence of the accused is the object of bail); People v. Durbin, 218 Cal. App. 2d 846, 32 Cal. Rptr. 569 (1963); People v. Walling, 195 Cal. App. 2d 640, 16 Cal. Rptr. 70 (1961). The use of the word primary implies that bail may serve other purposes in California, although there is little Califonia authority indicating for what other purposes bail may legitimately be used. Cf. In re Scaggs, 47 Cal. 2d 416, 419, 303 P.2d 1009, 1011 (1956) (other unatters, such as criminal activity if the accused is released, may be considered in determining whether a convicted accused should be detained on appeal).

Federal cases illuminate other possible purposes that bail may serve. In Stack v. Boyle, 342 U.S. 1 (1951), the Court states that an anount set that is more than is reasonably calculated to insure the presence of the accused is excessive. Id. at 5. It appears that if any purposes are served other than insuring the presence of the accused, the amount is excessive. Bail may be demied to the accused on appeal, however, if there is substantial evidence that the commumity may be threatened by his release, see Rehman v. Califonia, 85 S. Ct. 8, 9 (Douglas, Circuit Justice, 1964); Leigh v. United States, 82 S. Ct. 994, 996 (Douglas, Circuit Justice, 1962), or if the defendant may commit another atrocious offense or threaten witnesses. Carbo v. Unitcd States, 82 S. Ct. 662,666 (Douglas. Circuit Justice, 1962).

Denial of bail in California for purposes other than insuring the presence of the aceused has occurred only after the conviction of the accused and pending his appeal. See, e.g., In re Scaggs, supra. An inference that may be drawn is that the only purpose of bail before conviction is to insure the presence of the accused but upon conviction and appeal considerations other than risk of flight nay be relevant, since bail at that stage of the litigation is not a right but a matter of discretion. CAL. CoNST. art. I, $\S$ 6; Ex parte Voll, 41 Cal. 29 (1871); Cal. Penal Code $\$ 1272$ (West 1956). Thus the primary purpose of bail before or after conviction is to insure the presence of the accused. Neither high bail nor denial of bail is justified to punish the defendant, In re Newbern, supra; Reynolds v. United States, $80 \mathrm{~S}$. Ct. 30, 32 (Douglas, Circuit Justice, 1959); Johnson v. State, 30 Ala. App. 593, 10 So. 2d 298 (1942); because community sentiment is against the accused, Carbo v. United States, supra; In re Stegman, 112 N.J. Eq. 72, 163 A. 442 (1932); because the accused is a notorious law violator, 
the assumption that the accused may not appear unless he is required to post security with the court. ${ }^{8}$ In fact, the percentage of persons released prior to trial who fail to appear is quite low, averaging between two and three percent. ${ }^{9}$ The low mcidence of default among those released on bail suggests at first glance that fear of forfeiture may be a significant factor in their appearance. Some accused in all probability are deterred from leaving the jurisdiction by the posting of security. However, the risk of property loss alone does not account for the low rate of default, since other forms of pretrial release show equally low rates. ${ }^{10}$

Appearance results under the Illinois "ten percentum" system, ${ }^{11}$ for exainple, suggest that loss of property is not the only effective sanction against contemplated flight. Under the Illinois statute, an accused pays into court an unsecured amount equal to 10 percent of the bond set by the court, and gets 90 percent of this deposit refunded when he appears in court. This procedure can be viewed either as combining the negative sanction of property loss with the positive incentive of a refund upon appearance or, particularly in cases where modest bail is set, as ainounting to a potential property loss so small that it is not sufficient to deter flight. For example, an accused charged with disorderly conduct, and having bail set in accordance with bail anounts in one Califorma jurisdiction, would be required to post 500 dollars per count. ${ }^{12}$ Under the Illinois plan, assuming one count, he would pay into court 50 dollars, 90 percent of which would be returned to him upon appearance. In California, the same accused would be obligated to deposit

Cohen v. United States, 82 S. Ct. 8, 9 (Douglas, Circuit Justice, 1961); or because the accused has an evil reputation, Carbo v. United States, supra; Gusick v. Boies, 72 Ariz. 309, 234 P.2d 430 (1951).

8. A similar assumption applies to own-recognizance release: unless the accused has certain ties to the community, the risk that he will not appear is considered too great to allow release. Telephone interview with Martin Pulich, Judge, Municipal Court, Oakland-Piedmont (California) Judicial District, March 7, 1969 [hereinafter cited as Pulich interview].

9. See Freed \& Wald, Bail in the Unted States: 1964, at 29 (1964). Rates of forfeiture taken from bail surveys in urban areas ranged from .6 to 10 percent. Id. See Foote, Compelling Appearance in Court: Administration of Bail in Philadelphia, 102 U. PA. L. Rev. 1031, 1062 (1954) [hereinafter cited as Foote, Philadelphia Bail Study].

10. See, e.g., Ares, Rankin \& Sturz, Manhattan Bail Study, supra note 6, at 86 (1.2 percent of own-recognizance releasees failed to appear); Note, An Alternative to the Bail System: Penal Code Section 853.6, 18 HASTings L.J. 643, 644-46 (1967) (four California jurisdictions using non-bail release in misdemeanor cases reported three percent or less of suspects released failed to appear) [hereinafter cited as Note, Alternative to Bail]; OAK. REP., supra note 5, at 86 (5.9 percent and 4.4 percent respectively of misdemeanor and felony arrestees released on their own recognizance failed to appear).

11. 38 Ill. ANN. Star. ch. 38, \& 110-7 (Smith-Hurd 1964), as amended, (Supp. 1967).

12. Bail Schedule, Alameda County (on file with the California Law Review). 
the total amount of bail set, and even if he did appear, he would not get back the normal ten percent premium paid to the bondsman. ${ }^{13}$ Furthermore, the bondsman may require the California accused to put up collateral security. ${ }^{14}$ Although the California and Illinois accused appear to be similarly situated, only the former stands to lose a substantial imterest in property by flight from the jurisdiction. Yet default rates in Illinois appear to be as low as those for any California jurisdiction. ${ }^{16}$

There are nonpecumiary forms of release with default rates as low or lower than those of the California bail system. One example is the California own-recognizance release system, under which the judge evaluates the ties of the accused to the community, and releases the accused on his promise to appear without requiring the deposit of money with the court. This statutory procedure has resulted in the successful release of large numbers of felony and misdemeanor accused in some jurisdictions. ${ }^{16}$

The station-house release ${ }^{17}$ and the citation method ${ }^{18}$ are two hybrid fornis of own-recognizance release in California. Both procedures allow the arresting officer to release a misdemeanant immediately, imstead of taking him before a magistrate. The arrestee must sign a written promise to appear in court. ${ }^{10}$ At least four California juris-

13. Comment, California Bail System, supra note 1, at 1139. However, in Ca1ifornia, if the accused posts bail himself and appears in conrt, he gets back 100 percent of the deposit. Cal. Penal Code $\$ 1295$ (West Supp. 1968). Section 1295 applies only if the accnsed is charged with a misdemeanor and the amount of bail does not exceed 1000 dollars. Id. The accused may post the amount of bail specified on the arrest warrant or bail schedule in cash or by surety bond, id. $\$ 1269$ (b) (West Supp. 1968), or post a noncommercial bail bond which theoretically costs him nothing. See CaL. Ins. Code $\$ 1800.7$ (West Supp. 1968).

There are no longer any bail bondsunen in Illinois as a consequence of the ten percent bail deposit system. Hearings in S. 1357, S. 646, and S. 648 Before the Subcomm. of Constitutional Rights and the Subcomm. on Improvements in Judicial Machinery of the Senate Comm. on the Judiciary, 89th Cong., 1st Sess. 193 (1965) (testimony of Professor Charles Bowman) [hereinafter cited as 1965 Senate Staff Hearings].

14. Comment, California Bail System, supra note 1, at 1140. The bondsman requires the accused, his family, or friends to provide collateral security to protect the bondsman from loss in the event of bail forfeitnre.

15. Letter from Charles Bowman, Professor of Law, University of Illinois (cited in Comment, California Bail System, supra note 1, at 1172 n. 185) Preliminary reports on the operation of the Illinois system indicate that it functions adequately. See 1965 Senate Staff Hearings, supra note 13, at 191-92; STAFF OF SENATE COMM. ON THE Judiciary, 88Th Cong., 24 Sess., Report on Constitutional Rights and Federal BaIL Procedures 17 (Comm. Print 1965).

16. Telephone interview with Herbert Kutchins, director of the San Francisco Bail Project, March 7, 1969 [hereinafter cited as Kutchins interview]. The ownrecognizance system is authorized by CaL. Penal Code $\$ \$ 1318-20$ (West Supp. 1968).

17. CaL. Penal Code $\$ \S 853.6-.8$ (West Supp. 1968).

18. Id.

19. Willful violation of the proinise to appear is a misdemeanor, regardless of the disposition of the original charge. Cal. Penal Code $\S 853.7$ (West Supp. 1968). 
dictions liave applied similar release methods to non-traffic offenses, ${ }^{20}$ and the failure to appear rate has not exceeded three percent, whicli is as low or lower than the default rate for bail release in many jurisdictions throughout the country. ${ }^{21}$

The successful use of these alternative forms of pretrial release indicates that depositing bail with the court is not an indispensable factor in securing the appearance of accused individuals. Analysis of some of the reasons for nonappearance gives further evidence of the inadequacy of the monetary sanction theory. Most defaults are not willful. ${ }^{22}$ The great majority are technical defaults-nonappearance due to illness, appearance at the wrong court, or other excusable reasons. ${ }^{23}$ This pattern is also true of own-recognizance defaults. ${ }^{24}$

This data suggests that current bail law over-emphasizes the factor of nonappearance, and that the accused must consider other factors in addition to loss of bail when weighing the likelihood of conviction against the advantages of nonappearance. An accused may conclude that the possibility of conviction does not justify leaving family and community indefinitely, entermg seclusion, or attempting the difficult task of remaining outside the grasp of the law. But perhaps the principal reason the accused appears in court is that willful nonappearance presents the risk of recapture and the imposition of additional penalties. $^{25}$ In a nation with wide-open, sparsely settled territory, bail

20. Note, Alternative to Bail, supra note 10, at $644-45$. The four jurisdictions are Richmond, Sunnyvale, Pittsburg, and Contra Costa County. The accused arrested in any of these jurisdictions is screened for community ties at the police station before release. Id. San Francisco employs the citation release procedure of CAL. Penal Code $\$ 853.6$ (West Supp. 1968). Telephone interview with Harold Green, Chief of the Criminal Division, Sau Francisco Police Department, Nov. 19, 1969. Chief Green commented that the program was very successful. Other California law enforcement agencies infrequently use this form of release with Penal Code violations, although it is an established practice with Vehicle Code violations. Note, Alternative to Bail, supra note 10, at 643. See CaL. Veh. Code $\$ \S 40500-12$ (West Supp. 1968).

21. See notes $9 \& 10$ supra.

22. See Foote, The Coming Constitutional Crisis in Bail, 113 U. PA. L. REv. $1125,1162,1167$ (1965) (Vera Foundation study showed at least 89.8 percent of defaults iu New York City not due to willful nonappearance) [heremafter cited as Foote, Crisis in Bail].

23. Id.

24. See Ares, Rankin, \& Sturz, Manhattan Bail Study, supra note 6, at 86.

25. See Foote, Crisis in Bail, supra note 22, at 1163 . There is no penalty for fumping bail in California. See Comment, California Bail System, supra note 1, at 1152. An accused released on his own recognizance who willfully fails to appear commits au independent offense equal to the original charge. CAL. Penal Code $\$ \$ 1319.4,1319.6$ (West Supp. 1968). Imposition of penalties for bail-jumping-making nonappearance a criminal offense-have been adopted by New York and Minnesota. See Foote, Philadelphia Bail Study, supra note 9, at 1068. The New York provision makes the accused guilty of a crime equal to the seriousness of the original charge if he fails to appear for a criminal action or proceeding within 30 days of the required date. N.Y. PENaL LAW $\S \S 215.57-.59$ (McKinney Supp. 1969). The Minne- 
may have been one of the few ways to tie the accused to the jurisdiction. ${ }^{26}$ In a modern urban society, however, with sophisticated communications systems and imcreasing coordination by local, state, and national law enforcement agencies, more consideration should be given to the deterrent effect of the risk of recapture, ${ }^{27}$ and less to risk of property loss.

sota provision makes the accused liable for either a 1000 dollar fine or imprisonment for not more than one year, or both, for intentional failure to appear without lawful excuse within three days of the required date. MinN. STAT. ANN. $\$ 609.49$ (West 1964). These statutes have apparently had a deterrent effect. Foote, Philadelphia Bail Study, supra note 9, at 1068-69, nn.144 \& 148. The federal system utilizes several sanctions against flight. 18 U.S.C. $\$ 1073$ (1964) provides that it is a federal offense punishable by a 5000 dollar fine or five years in prison, or both, to flee across a state line to avoid prosecution for a felony. This statute is used by district attorneys as the equivalent of a state bail jumping statute, but its use in Northern California has been limited by the United States Attorney. Comment, California Bail System, supra note 1, at 1168 n.168, 18 U.S.C. \& 3150 (1964) provides that failure to appear on a felony charge is punishable by five years in prison or a 5000 dollar fine, or both; failure to appear on a misdemeanor charge is punishable by a fine not more than the maximum provided for such misdemeanor or imprisonment for not more than one year or both.

26. See Comment, Bail: An Ancient Practice Reexamined, 70 Yale L.J. 967 (1961).

27. In California recapture of bail-jumpers is the responsibility of the bail bondsman. Cal. Penal Code $\$ 1305$ (West Supp. 1963). The bondsman has 180 days in which to cither locate the fugitive and return him to court, or present a satisfactory excuse for his failure to appear. Id. The power to recapture an accused is based on the contractual relationship between the partics and exists independently of statutory authorization. Comment, California Bail System, supra note 1, at 1163. Thus, jurisdictional boundarics do not limit the bondsunan's power, and the bondsman may enploy a "skip tracer" to locate the fugitive out-of-state accused. Id.

Opinions vary as to the effectiveness of private recapture of defaulting accused. Bondsmen have been characterized as an aggressive group who relentlessly pursue the skipping accused, an attitude that puts the "fcar of God" into accused since they know what to expect in the event that they skip bail. See Foote, Philadelphia Bail Study, supra note 9, at 1067. Others maintain that bondsmen perform no significant recapturing function. Foote, Crisis in Bail, supra note 22, at 1162. There is no statistical information available as to the adequacy with which California bondsmen perform their retrieval function. Comment, California Bail System, supra note 1, at 1169.

A substantial number of accused are probably located by public officials. Id. at 1161. The rate of recapture is probably high. Many accused are continuously in trouble with the law, and the probability of rearrest within six months, and subsequent discovery of their fugitive status, is a virtual certainty. See id. at 1145 n.67.

An accused may believe that he faces a substantial likelihood of recapture. While working as a student interviewer at the San Francisco Bail Project, this writer found that many arrestees expected to be arrested again. They believed that they were bound to be involved in a future criminal violation. This psychological expectation has not been evaluated by law enforcement officials, although it may be an clement in the accused's estimation of the risk of recapture upon nonappearance. Cf. K.R. EIssLER, Ego-Psychological Implications of the Psychoanalytic Treatment of DelinQUENTS 97-121 (1952). 


\section{B. The Seriousness of the Charge Does Not Increase the Probability of Default}

The belief that the seriousness of the cliarge increases the probability of default is contradicted by the evidence. Although default rates for misdemeanor and felony arrestees are low, nonappearance is more likely to occur among misdemeanants than among felony offenders.

Bail law in California reflects the notion that the risk of default increases with the seriousness of the charge ${ }^{28}$ and the characterization of the offense. ${ }^{29}$ The correlate of this assumption is that the bail amount should increase correspondingly. But neither the assumption nor its correlate makes sense in terms of the bail system's primary goal of insuring the presence of the accused. Defaults are more likely to occur among misdemeanor than felony accused in any current system of release. $^{30}$ If a relationship can be established between the character of the offense and the likelihood of appearance, it is an inverse one.

The purpose of the fixed bail schedule in California ${ }^{31}$ is to facilitate the speedy release of the accused by obviating the need for individual determinations in every case. The bail schedule is efficient in moving the solvent accused through the pretrial detention period, but its overall effect on release is deleterious. Some accused persons are precluded from securing release because they cannot pay the statutory amount, a figure which is necessarily arbitrary in that it reflects only the serious-

28. Pulich interview, supra note 8. See CAL. PENAL CoDe $\& 1275$ (West 1956), which requires the inagistrate, in fixing the amount of bail, to take into consideration the seriousness of the offense charged, the previous criminal record of the accused, and the probability of his appearing at the trial or hearing of the case.

29. See Bail Schedule, Alameda County (on file with the CaLIForNia LAw REVIEW).

30. See Foote, Philadelphia Bail Study, supra note 9, at 1061-62. Of the 264 forfeitures in Philadelphia in 1950, there were two bail jumpers charged with forgery, five for sodomy, 10 for narcotics offenses, and none for burglary, robbery, rape, arson, and voluntary mansiaughter. Nearly one-half of the forfeitures involved gambling, liquor, or traffic offenses. Id. The Oakland Bail project reported that the rate of nonappearance among project-investigated cases released on own recognizance between September, 1964 and August, 1966 was 5.9 percent for misdemeanors and 4.4 percent for felonies. OAK. REP., supra note 5, at 86. The District of Columbia Bail Project reported that of the 350 defendants (190 felony and 160 misdemeanor) released on their own recognizance during 1964, 12 of the 13 defaulting defendants faced misdemeanor charges at the point of default. McCarthy \& Wald, D.C. Bail Project, supra note 6 , at 714 .

31. Cal. Penal Code $\S 1269$ (b) (West 1956). The schedule is established by the judges in each county and sets a standard amount per crime which the accused is obliged to post. Although statutory authorization for the bail schedule extends only to misdemeanors, some California jurisdictions also use a bail schedule for felonies. Comment, California Bail System, supra note 1, at 1165. The bail schedule is based on the alleged interdependence between the amount of bail and the seriousness of the charge, see text accompanying notes $28-30$ supra. 
ness of the charge and not the factual circumstances of the individual case. Standardization of the bail amount institutionalizes the sum required for release; the accused who goes before the trial court to protest the schedule amount as unreasonably high must show why he should be released for an amount less than the schedule or court-fixed level. The accused who appeals on the basis that the amount set is excessive must surmount the additional hurdle of the deference given by the appellate courts to the discretion of the trial courts in setting bail..$^{32}$

Characterization of the offense provides some idea of the significance that society attaches to a misdeed. Felonies are usually more serious transgressions agaimst the social order than misdemeanors. It is interesting to note that in California, over 85 percent of all arrests are for misdemeanor offenses. ${ }^{33}$ It is difficult to understand why the state need protect its interest by requiring bail from the entire arrest population, when the vast inajority of accused will appear, and when the vast majority of crimes for which they have been arrested are those that society has designated as relatively minor.

\section{Own-Recognizance Release: Limitations of the Community Ties Standard}

The belief underlying the own-recognizance section of the bail systein is that an accused should be released on his own recognizance only if he has ties to the community. This philosophy is erroneous and unfair because own-recognizance standards reflect middle-class values which do not consider the characteristics of either the poor or the young.

In 1959 the Legislature grafted an own-recognizance release procedure onto the state bail system. ${ }^{34}$ Under section 1318.6 of the Penal Code, an accused who could be released on bail can be released from custody upon good cause being shown, if it appears that the accused will surrender himself at the proper time to custody. ${ }^{35}$ The own-recogni-

32. See In re Brumback, 46 Cal. 2d 810, 815, 299 P.2d 217, 220 (1956) (trial judge's ruling will not be disturbed unless a manifest abuse of discretion appears); Ex parte Morehead, 107 Cal. App. 2d 346, 349, 237 P.2d 335, 337 (1951) (must be apparent per se that amount fixed is unreasonably great and clearly disproportionate).

33. See 1967 Cal. Bureau Crim. Stat. AnN. Rep. 76, 79. San Francisco reported 85,916 arrests in 1966 for all crimes. 82,287 of these arrests were for inisdemeanors, and 3629 represented felony arrests. 1966 SAN Francisco Police DeP'T ANN. REP. 26-36.

34. Cal. Penal Code $\S 1318.4$ (West Supp. 1968). "A recognizance is an agreement in writing filed with the court in which the defendant agrees to appear at all times and places as the court orders, and to waive extradition if he is apprehended outside of California after failing to appear." Comment, California Bail System, supra note 1 , at 1152 .

35. Cal. Penal Code $\S 1318.6$ (West Supp. 1968). Willful failure to appear is a crime equal in seriousness to the original charge. Id. $\S \S 1319.4,1319.6$. 
zance procedure allows the court to release the accused who cannot make bail. The usual procedure is to review the criminal record, residential stability, employment history, and family contacts of the accused and assess the effects of these community ties on the risk of nonappearance. ${ }^{36}$

Although own-recognizance release enables an accused to secure his freedom when he might otherwise have remained in jail for lack of funds, the procedure contains many of the shortcomings of the bail system. The criteria upon which own-recognizance release is premised are patently middle class-they may have little relevance to many potential arresteees. ${ }^{37}$ Unemployment and underemployment are high among arrestees, residential instability and transience are characteristic, and a prior criminal record is common. ${ }^{88}$

The use of middle-class standards also contains a built-in cultural bias agamst certain minority groups. For index crimes, ${ }^{39}$ the national

36. Often the initial investigation of the background of the accused is done by a pretrial release project, e.g., San Francisco Bail Project, or a law enforcement agency, e.g., Oakland Pre-Trial Release Project (probation department officers), with the final decision as to release remaining with the court.

37. See, e.g., notes 41 and 43 infra; CIvIL Disorders, supra note 4, at 123-36. A large segment of the American population have incomes below the poverty level. 1d. at 258-59. It is beyond dispute that members of this group, as arrestees, would have great difficulty meeting at least some of the requirements of release on own recognizance.

However, the proposition that community ties as a basis for release on own recognizance are too restrictive because they are middle-class does not mean these standards do not accurately distinguish between those accused who are inore likely and those less likely to appear. Unfortunately, they are not meaningful for a large portion of those arrested. But commumity ties are only one deterrent among several available in fashioning a system of release. The risk of recapture and penalties for willful nonappearance are a threat to any accused, whether or not he has ties to the community. The risk of recapture and the vigorous prosecution of those accused who willfully default, coupled with the use of community ties when the accused possesses them, see text accompanying notes 77-78 infra, would provide a far more flexible, and more relevant system of release than connmumity ties alone, in light of the large number of poor, minority members, and young who cannot qualify under current own-recognizance standards.

38. See, e.g., OAK. REP., supra note 5, at 40-53. In 1965, 64 and 66 percent respectively of the felony and misdemeanor applicants for release on own recognizance were unemployed. The inajority of those who were employed had held their jobs for a relatively short time, 25 percent of the employed group having been in their present jobs less than one month, and only 40 percent having held their jobs more than one year. 50 percent of the applicants had been living at their present address six montlis or less. Approximately two-thirds of the applicants had a criminal record, and roughly 40 percent had four or more convictions. Id.

39. The Crime Index represents seven crime classifications used by the Federal Bureau of Investigation to establish an index to measure the trend and distribution of crime in the Umited States. The crimes included are murder, forcible rape, robbery, aggravated assault, burglary, larceny involving 50 dollars or more, and auto theft. UNIFORM CRIME REP. 4 (1966). 
arrest rate for Negroes is about four times higher than it is for whites. ${ }^{40}$ It is far more difficult for a black arrestee to meet own-recognizance release criteria than his white counterpart. ${ }^{41}$ It is probable that a large number of the poor are represented in the Negro arrest group. ${ }^{42}$

Both own-recognizance and bail release place a premium on factors not characteristic of young people, who constitute a substantial portion of the arrest population. ${ }^{43}$ It is not characteristic of this group to have established lasting residential and employment ties to the community. This is particularly true of Negro youths, who account for a disproportionate amount of crime, ${ }^{44}$ but have the greatest difficulty meeting own-recognizance standards.

\section{Pretrial Freedom and Societal Interest: Beyond the Bail System}

The primary purpose of pretrail release in the United States is to allow the accused his pretrial hiberty while assuring his appearance in court. $^{45}$ An analysis of the evidence will suggest some possible alter-

40. See CiviL Disorders, supra note 4, at 136.

41. E.g., the median income for a Negro family was only 58 percent of the white median in 1966. Id. at 123. Negro unemployment rates are double those of white and reached 8.2 percent in 1967. Id. at 124.

42. See 1966 San Francisco Police Dep't Ann. Rep. 26-36. In San Francisco, of the 20,149 arrests made in 1966 for all crimes excluding traffic and drunkenness, 10,188 were white, 9,433 were Negro, and 528 were other minority groups. Thus Negroes, representing 12 percent of the San Francisco population, account for nearly 50 percent of the arrests. If San Francisco follows the pattern of most major metropolitan areas in the United States, 41.7 percent of its minorities are "poor." See CTVIL DISORDERs, supra note 4, at 127.

43. See e.g. 1967 Cat. Bureau Crim. Stat. Ann. Rep. 135-36. Nearly onehalf of all the defendants convicted of felomies in Californin in 1967 were under 25 years of age. Id. In 1966, persons under 25 years of age were arrested for 37 percent of tho murders, 60 percent of the forcible rapes, 71 percent of the robberies, 81 percent of the burglaries, about 75 percent of the larcenies, and over 80 percent of the auto thefts committed in the Umited States. Crvil Disorders, supra note 4, at 136. Persons aged 20 to 24 were the largest group of individuals arrested for felonies in California in 1967-over 32 percent. 1967 Cal. BuReau Crim. Stat. ANN. ReP. 135-36. Those aged 25 to 29 accounted for another 16.5 percent. Id.

44. CTVIL Disorders, supra note 4 , at 136.

45. See note 6 supra; see Foote, Introduction: The Comparitive Study of Conditional Release, 108 U. PA. L. REv. 290, 293 (1960) [hereinafter cited as Foote, Comparitive Conditional Release]. In many foreign legal systems bail serves multiple purposes. Public safety is a frequent criterion for detention. The accused may be denied release if he will continue to commit the offense before his case is concluded, or if exceptional circumstances would justify the fear that the offense will be repeated. Id. at 294-95. Habitual offenders or those previously convicted of an offense punishable by death or imprisonment for a maximum period of more than a certain number of years may also be detained. Dando \& Tamiya, Conditional Release of an Accused in Japan, 108 U. PA. L. REv. 323, 325 (1960). Other systems allow detention if the accused, while at liberty, would obstruct the administration of justice in his particular case. Id. Detention of the accused is permitted if there is a likelihood of tampering 
natives to the balance struck between these two considerations under current law.

The present system of pretrial release pays little heed to the interest of the individual. Pretrial freedom protects tangible interests for the accused besides freedom from confinement itself. One of the most significant advantages of pretrial freedom is the opportunity it affords for trial preparation. ${ }^{48}$ Witness location, an important function of pretrial

with the evidence or of intimidation of witnesses. Smith, Bail Before Trial: Reflections of a Scottish Lawyer, 108 U. PA. L. REv. 305, 309 (1960); Dando \& Tamiya, Conditional Release of an Accused in Japan, supra, at 326; Bratholm, Arrest and Detention in Norway, 108 U. PA. L. REv. 336, 337 (1960).

The proposed statute, see Part II infra, is silent on aspects such as danger to the community if the accused is released, the probability of the accused committing further crimes, and the risk of his interfering with the conduct of his trial. These possibilities pose a comparatively minor threat when assessed in terms of the total number of accused who are eligible for release under the proposed system. See Foote, Crisis in Bail, supra note 22, at 1170 (although there is no data on the probability that an accused will commit a serious crime during the pretrial period, it is inconceivable that the probability is higher than five percent and more likely it is considerably lower); Address by Herman Goldstein, Executive Assistant to the Superintendent of Police, Chicago, Ill., reprinted in PROcEEDINGS aNd INTERIM REPORT OF THE NAT'L CONFERENCE ON BaIl and Criminal Justice 151-65 (1965); OAK. ReP., supta note 5, at 23, 88-89 (11.6 percent felony arrestees rearrested while on own recognizance, but none on original charge and only one for subsequent charge of violent or assaultive behavior). Covering these possibilities in the statute would require standards too vague to administer. A statute incorporating the proviso that the accused cannot be released if le presents danger to the community implies an untrammeled discretion in the court to decide these matters. A judge would be hard-pressed in arriving at any standard that would accurately predict future human conduct. See Foote, Crisis in Bail, supra note 22, at 1169-74. A judge's estimate about the future activity of an individual creates the possibility that an innocent accused may be unnecessarily detained. As Professor Foote has stated, "the justifiable statistical assumption of probability that the accused is guilty of the offense charged easily invites the much more dubious assumption of probability of criminality while on conditional release." Foote, Comparative Conditional Release, supra, at 294. But see S. 2920, 91st Cong., 1st Sess. (1969) (proposing an annendment to the Federal Bail Reform Act of 1966 which would authorize consideration of au accused's danger to the community in setting conditions of release, and to provide for preventive detention of dangerous persons); H.R. 14822, 91st Cong., 1st Sess. (1969) (proposing, inter alia, to strengthen controls over dangerous individuals released prior to trial, and to provide means for effective supervision and control of such individuals).

46. See Stack v. Boyle, 342 U.S. 1, 4 (1951). Adeqnate preparation of a defense is significantly hampered when the accused is detained. Communication is restricted since connsel must travel to jail to consult his client, a place often geographically remote from his office. See Foote, Crisis in Bail, supra note 22, at 1147. This problem, in aggravated form, is exemplified by the pretrial dilemma of an accused in Oakland. Once he has been arraigned, and is either unable to make bail or refused release on his own recognizance, the accused is transferred to the Santa Rita Detention Facility, some 30 miles from Oakland, and remains there for the duration of his pretrial period. The conditions of jail may not be conducive to effective consultation. See Note, A Study of the Administration of Bail in New York City, 106 U. PA. L. Rev. 693, 723 (1958) [hereinafter cited as New York Bail Study]. Facilities may be limited to a small room, or the accused may be physically separated from his attorney by a win- 
investigation and a task peculiarly within the knowledge of the accused, is affected adversely. ${ }^{47}$ Nor can the accused, in cases without merit, persuade the prosecutor or complaining witness to have the charges against him dropped. ${ }^{48}$ The quality of the attorney-chent relationship may also be impaired..$^{49}$ The fact that the accused has been detained may adversely affect the judge and jury at trial. ${ }^{50}$ But perhaps the most drainatic illustration of the practical importance of pretrial freedom are the differences in the disposition rates of jailed and released accused. The accused released on bail on his own recognizance is less likely to be convicted, and if convicted, is less likely to receive as severe a sentence as the detained accused. ${ }^{61}$

One can legitimately question the present bail system in light of the prejudice to the accused and the insubstantial danger to the state interest involved. ${ }^{52}$ Clearly the state has a compelling interest in bringing the

dow or screen, and able to communicate only by speaking through a window opening or a phone. Id.

47. See Foote, Crisis in Bail, supra note 22, at 1141-42.

48. Foote, Philadelphia Bail Study, supra note 9, at 1052; R. GoLDFARB, RANSOM: A CRITIQUe OF THE AMERICAN BAIL SYSTEM 41 (1965) [hereinafter cited as GoldFARB].

49. Foote, Crisis in Bail, supra note 22, at 1147. See note 46 supra.

50. GoldFARB, supra note 48, at $41-42$. The person who has remained in jail is brought into the courtroom under guard in contrast to the accused who enters the courtroom freely with counsel and, perhaps, his fainily. Id. In the latter case, the accused is demonstrating that he can function in society as a responsible citizen between arraignment and disposition, a subtle but persuasive fact. The courtrooin reaction to the jailed and released accused may explain why the jailed accused has higher conviction rates by juries and more severe sentences imposed on him by judges. See note 52 infra.

51. Foote, Philadelphia Bail Study, supra note 9, at 1051-54; Ares, Rankin \& Sturz, Manhattan Bail Study, supra note 6, at 84-86. Rankin has shown that the statistical relationship between pretrial detention and unfavorable disposition is a causal one. The study held constant the previous record, bail amount, type of counsel, and family integration of the accused. Rankin, The Effect of Pretrial Detention, 39 N.Y.U.L. REv. 641, 652-54 (1964). Accused persons released before adjudication who are subsequently convicted fare substantially better with regard to the sentence imposed. Foote, Philadelphia Bail Study, supra note 9, at 1053. Pretrial detention has also been hypothesized to affect adversely the probability of successful rehabilitation. Foote, Crisis in Bail, supra note 22, at 1148; Wald, Forward, Pretrial Detention and Ultimate Freedom: A Statistical Study, 39 N.Y.U.L. Rev. 631, 63435 (1964).

Arguably the difference in disposition rates between jailed and bailed accused could be attributed to the efficiency of the present bail system in keeping the guilty offender in jail. The guilty accused remains in jail and is more likely to be convieted because the judge, knowledgeable in all the circumstances of the case, has prudently exercised his discretion in setting bail higher in those cases in which he believes the accused is guilty. However, judges are infrequently fully apprised of the circumstances surronnding a particular arrest, see text accompanying notes 81-82 infra, and no matter what the amount of bail set, it is the financial inability of the accused that keeps one accused in jail and enables another to go free before trial.

52. See text accompanying notes $9 \& 22$ supra. The state interest is not endangered because few accused fail to appear. Most of those that do default fail to appear for a minor charge and for a technical reason. 
accused to trial, but the means by which this end is presently achieved are unnecessarily restrictive of the freedom of the individual. Given the vast preponderance of misdemeanor arrests, the likelihood that default rates would not increase if all accused were released, ${ }^{53}$ and the deleterious effects of detention on the accused, it is difficult to justify bail as a mode of release. Under the present system, the state's interest is over-protected at the expense of the accused's interests. In a nation that has in theory placed a high value on the freedom of the imdividual, the bail system appears to be an anoinaly. Since any system of pretrial release deals with human conduct, an element of unpredictability is always present. $^{54}$ But it is unfair to incarcerate a large number of individuals because of the supposition that a few will flee the jurisdiction, and to premise a system of pretrial release on the assumption that default is the norm, when individuals are consequently demied their freedom.

In developing an improved systein of pretrial release two goals should be set: the Inaximization of release and the minimization of nonappearance. Even a system that releases all accused without bail will not significantly endanger the interest of the state.

II

\section{A PROPOSAL FOR REFORM}

\section{A. Outline}

The following proposed pretrial release statute is a synthesis in part of the present California pretrial release procedure and the Federal Bail Reform Act of $1966 .{ }^{55}$ It would replace California Penal Code sections 1268-1320. The statute protects the interest of the accused by extendimg an absolute right of release to all accused. Bail is eliminated. The interest of the state in assuring the presence of the accused at the proper time is also protected. Low default rates are maintained by utilization of half-way measures designed to keep the accused in regular contact with law enforcement agencies. Ample safeguards against unnecessary detention are provided by immediate appellate review of any detention, and a maximum imprisonment period before trial. The court inust consider all the circumstances of a case in deciding the mode of release. The discretion of the judge to refuse release or set high bail is eliminated, but he is given power which enables him to be imaginative in tailoring the conditions of release to fit the circnmstances of the individual case. It is left to local authorities to determine

53. Cf. Foote, Crisis in Bail, supra note 22, at 1169.

54. See id. at 1170.

55. 18 U.S.C. $\S 3146-52$ (Supp. IV, 1965-68). 
which offenses require an appearance before a magistrate. Strong sanctions for nonappearance are provided.

\section{B. Exegesis}

An act to repeal Chapter 1 (commencing with Section 1268), Title X, Part Two of the California Penal Code, relating to bail; and to add Articles 1,2,3,4,5, and 6 (commencing with Section 1271) to Chapter 1 of Title $X$ of Part Two of the California Penal Code, relating to pretrial and postconviction release.

The people of the State of California do enact as follows:

Section 1. Chapter 1 of Title $\mathrm{X}$ of Part Two of the California Penal Code is repealed.

Section 2. Chapter 1 (commencing with Section 1271) is added to Title $\mathrm{X}$ of Part Two of the California Penal Code to read as follows:

$\S 1271$. Right to Release. A person shall be released after arrest as a matter of right..$^{56}$

This section eliminates the pecuniary contingency ${ }^{57}$ to the right of pretrial release and extends release to all offenses including those punishable by death. ${ }^{58}$ Abolition of bail as a prerequisite of release re-

56. CAL. CoNST. art. I, $\S 6$ provides: "All persons shall be bailable by sufficient sureties, unless for capital offenses when the proof is evident or the presumption great. . . "The proposed section 1271 may require a constitutional amendment in order for those capital accused coming within the limitation of section 6 to be relcased.

57. CaL. Penal CODE $\$ 1271$ (West 1956) provides: If the charge is for any other offense [other than an offense punishable by death when proof of guilt is cvident or the presumption thereof great], he may be admitted to bail before conviction, as a matter of right. Both the present statute and the proposed section 1271 afford relcase to the accused as a matter of right. The difference between the two is that the proposed section 1271 does uot base the right of release on a financial condition.

As with current law, the proposed section places the risk of nonappearance on the state. Bail law has in theory always allocated this burden to the state. "Admission to bail always mvolves a risk that the accused will take flight. That is a calculated risk which the law takes as the price of our system of justice ... . [T]he spirit of the procedure is to enable them to stay out of jail until a trial has found them guilty." Stack v. Boyle, 342 U.S. 1, 8, (1951) (Jackson, J., concurring).

58. CaL. Penal Code $\S 1270$ (West 1956) provides: "A defendant charged with an offense punishable with death cannot be admitted to bail, when the proof of his guilt is evident or the presumption thereof great. The finding of an imdictment does not add to the strength of the proof or the presumptions to be drawn therefrom." The proposed section 1271 eliminates the distinction made under current law between an offense punishable by death and an offense punishable by death where the proof of guilt is evident or the presumption thereof great for several reasons. First, the historical basis for the distmction is not justified under the proposed statute, see notes 61-62 infra and accompanying text; second, the distinction stretches the concept of legal discretion to the limit, and is in fact a prejudgment of the merits of the case; third, the proposed statute provides the means to assure the presence of any accused in court at the designated time, see proposed section 1274 infra; and because if the safety of the community is threatened by the release of the accused, a court under existing law has ample power to deal with the situation, see proposed section 1280 infra. 
flects a rejection of the assumption that the accused will not appear without pecuniary compulsion. The rarity of default, the minor character of most offenses, the sanction of apprehension, and the tangible advantages of pretrial freedom militate against the burdening of the accused with financial ties and therefore against the present bail system.

The California Constitution secures to the citizen accused the right to bail in all cases except when charged with a capital offense "when the proof is evident or the presumption great."59 This exception is based upon the effect of an indictment at common law, ${ }^{60}$ which furnished per se a presumption of guilt of the capital accused too great to entitle him to bail. ${ }^{61}$ Given the strength of the cominon law indictnient and the primary purpose of bail in California-insuring the accused's presence in court-it would appear that this exception was originally premised on the behef that in such cases the accused would flee. But there is no reason to assume that he perceives the inevitability of conviction more than an accused charged with a lesser crime. ${ }^{62}$

§ 1272. Misdemeanors: Summons in Lieu of Arrest.

(a) In any case in which a person is arrested for an offense declared to be a misdemeanor, and does not demand to be taken before a magistrate, the arresting officer shall issue a written notice to appear in court. The notice shall be prepared in duplicate, and shall contain the name and address of such person, the offense charged, and the time and place when and where such person shall appear in court.

(b) The time specified in the notice inust be at least ten days after arrest. The place specified in the notice shall be the court of the magistrate before whom the person would be taken if a demand

59. CAL. Const. art. I, $\S 6$.

60. See People v. Tinder, 19 Cal. 539, 543 (1862). An indictment was unimpeachable at common law. See id. at 545 .

61. Id. at 543. This rule was undermined in California in 1872 when section 925 of the Penal Code was amended to require that a transcript be kept of the testimony introduced before the grand jury in all criminal cases where an indictment is returned, making an indictment impeachable. See Greenburg v. Superior Court, 19 Cal. 2d 319, 322, 121 P.2d 713, 715 (1942). The Legislature amended section 1270 of the penal code in 1872, apparently in response to People v. Tinder, 19 Cal. 539 (1862) (see note 60 supra), with the phrase "The finding of an indictment does not add to the strength of the proof or the presumptions to be drawn therefrom." CaL. PENAL Code $\$ 1270$ (West 1956). This evidences an intent to continue to leave the release of capital accused in the discretion of the judge. One likely reason is that only the judge before whom the capital accused appears can decide if the evidence is such that no amount of bail can insure his appearance.

62. Although conviction for the capital offender is no more inevitable than for the non-capital offender, the severity of the penalty may make the disadvantages of flight froin prosecution worth the risk. However, the court can impose restrictions under proposed section 1274 that enable both the court and other law enforcement agencies to keep a close watch on the accused's whereabouts. The court can also utilize community ties when available. 
for appearance before a magistrate had been made.

(c) The arrested person, in order to secure release, must give his written promise to appear by signing the citation. Proper identification must be shown on request. The arresting officer shall forthwith release the person arrested from custody when that person has satisfactorily identified himself and promised to appear. The arresting officer must so release the arrested person from custody within a reasonable time, taking into account the circumstances of the case.

(d) Any person resisting arrest may be brought before a magistrate in the manner provided for by section 1273.

This provision provides for the release of a misdemeanor arrestee after arrest and the issuance of a citation. The provision includes all misdemeanors on the assumption that appearance before a court is primarily for the purpose of setting bail, a requirement that no longer exists under the proposed statute. This nethod of release could be extended to felony cases, or contracted to cover only selected misdemeanors if certain minor offenses appeared to require the attention of a magistrate $^{63}$ The proposed statute adopts much of the citation release procedure of section 853.6 of the California Penal Code and an identical procedure in the California Vehicle Code which is applied to traffic violations. ${ }^{64}$

There are several objections to applying the citation release procedure in non-traffic misdemeanor cases. Unless the accused is taken into custody, he may not be sufficiently impressed with the gravity of his offense. The danger is that he might be less likely to prepare his case or retain counsel. Although first offenders inight not be familiar with the system, the citizenry would soon learn to associate the summons or citation with the gravity of the charge and the need to prepare an adequate defense in much the same way that arrest under the current system fulfills this function. A second objection is that the booking process ${ }^{65}$ might be initially hampered by the citation release procedure. But there should be no serious problen in revising the pretrial booking process to adapt to the demands of the new system. An accused, for example, might be required to appear within five

63. For convenience, a criminal offense that requires an appearance before a magistrate under this statute is designated a felony. Such a distinction is not necessarily relevant to the likelihood of appearance. Note, Alternative to Bail, supra note 10, at 654; see note 30 supra and accoinpanying text. The proposed statute leaves to the agreement of the judges of the local jurisdiction the types of offenses that require an appearance before a magistrate. This flexibility allows local authorities to require an appearance of an accused charged with an offense they believe merits close examination by the court.

64. CAL. VeH. Code $\S \S 40500-12$ (West Supp. 1968).

65. The fingerprinting, photographing, and recording of information about an arrestee after arrest and before his bail is set. Telephone interview with Deputy McEvers, Alameda County Jail, Nov. 19, 1969. 
days at a police station in the jurisdiction in which the citation was given to have his fingerprints and mugshot taken. These two incidents of arrest have traditionally been liandled during the detention period following arrest. Penalties for noncompliance could be created or included in proposed section $1277 .{ }^{66}$ Release from custody within a reasonable time might include the period necessary for the officer to call the local precinct for a computer check to see if the accused is wanted elsewhere and to take fingerprints and mugshot pictures of the accused. ${ }^{67}$ The accused could retain counsel before arraignment or, if he were financially unable to do so, counsel could be appointed by the court at the time of arraigninent.

Applying the citation release procedure to misdemeanor arrests might prevent a desirable cooling off period that is provided when the accused is detained at the jail. Certain offenses, such as wife-beating, may be followed by further violent acts on the part of a short-tempered husband. The statute's flexibility, however, permits the local judges to require violent or assaultive misdemeanants to appear before a magistrate. ${ }^{.8}$

The release procedure might also eliminate the valuable screening function that a formal arrest fulfills. ${ }^{69}$ The subsequent trip to the police station gives the arresting officer a chance to reflect upon his actions away froin the scene and to drop weak cases. ${ }^{70}$ But an officer can reconsider his actions and the circumstances of the arrest equally as well during the period between the release of the misdemeanant and the filing of the charges.

$\S$ 1273. Felonies: Station House Release. ${ }^{71}$ In any case in which a person is arrested for an offense declared to be a felony, the arresting officer shall, if such person is not otherwise released under section 1272 , take such person to the nearest or most accessible police facility in the jurisdiction without unnecessary delay. The arrested person may be ordered released unconditionally on his own recognizance by

66. See text discussion of proposed section 1277 infra.

67. A computer system currently in use in the San Francisco Bay Area allows police on patrol to check license plates on suspicious vehicles and to ascertain whether there is a warrant of arrest issued for persons detained momentarily. The officer checks the identity of the detained suspect by calling the "data center," and, if there is a warrant, verifies it with the law enforcement agency reported to have issued the warrant. Telephone interview with Captain Bennet, Hayward Police Department, Nov. 19, 1969.

68. See text accompanying note 63 supra.

69. Comment, California Bail System, supra note 1, at 1154, n. 103.

70. Id.

71. The station-house release has been successfully applied to misdemeanor offenders, see text accompanying note 20 supra and it has been recommended that police authorities be given discretion to extend the practice to felony accused. Note, $A l$ ternative to Bail, supra note 10 , at 645 . 
the officer in charge. If not so ordered, the accused shall be taken promptly for an appearance before a inagistrate.

This provision provides that the officer in charge at the station to which a felony arrestee is taken may authorize his release or require him to appear before a magistrate. ${ }^{72}$ This procedure seems workable since the arresting officer may well have sufficient knowledge of the facts for the officer in charge to authorize release. If the officer in charge believes that the circumstances of the case merit scrutiny by the court, he must order the arresting officer to take the accused before a magistrate promptly for release under section $1274 .{ }^{73}$

$\S 1274$. Provisional Release. Any person charged with a criminal offense shall, if an appearance before a magistrate is required, be ordered released unconditionally on his own recognizance, unless the court determines, on the basis of convincing evidence, that the accused will flee. In such a case, the magistrate may impose the following conditions or any combination thereof: $\mathrm{He}$ may (1) place the person in the custody of a designated person or organization agreeing to assume responsibility for him; (2) place restrictions on the accused person's travel, association, or place of abode during the period of release; (3) provide for supervision by a probation officer; (4) require the accused to return to custody after daylight hours on conditions designated by the judge; or (5) impose any other condition which the magistrate reasonably believes will deter flight, provided that no financial deposit shall be required. ${ }^{74}$ The court shall, in

72. See text accompanying note 63 supra. A jurisdiction might find that selected felonies also merited release by the citation release procedure.

There is the danger that police officers will tend to charge a felony against the accused, even where the circumstances do not merit the eharge, so that the arrestee can be taken to jail. This procedure can amount to no more than harassment, since, once he is taken to the station, the accused must forthwith be released unconditionally or promptly taken before a magistrate. However, the accused retains a police record with a felony arrest long after he is released or the charges are reduced to a misdemeanor. This may hamper future employinent opportunities. Special legislation might be required to provide that a felony arrest of an accused arrested under proposed section 1273 be stricken from his arrest record if his charges are subsequently reduced to a misdemeanor.

Police officers may legitimately distinguish between misdemeanors and felonies, but require all felony accused, regardless of need, to appear before a magistrate. However, the possibility of abuse is slight. Since the accused is in no danger of losing his liberty, an indiscriminate police policy of taking all felony accused before a magistrate can amount to no more than harassment. Furthermore, the court can limit the kinds of felonies or kinds of circumstances in which the arrest was made that require an appearance. See note 64 supra.

73. The station-house release could be expanded to include selected misdemeanors, see note 63 supra.

74. An alternative provision, seeking to implement the Illinois procedure, see note 10 supra and accompanying text, would not be acceptable because such a financial provision, in order not to prejudice the accused financially or detain him beeause of inability to post the required amount, would require limitations on the amount the court could set. The following provision serves as an example: 
determining the applicability of conditions, conduct an inquiry into the circumstances of the arrested person. The inagistrate imposing the original conditions of release may amend his order at any time after the appearance of the accused. The magistrate shall set forth in writing the reasons for the conditions imposed or any amendment to the original conditions. ${ }^{75}$

This provisional release section defines the limits of the court's discretion in setting conditions for release, takes cognizance of the noneconomic ties an accused inay have to a jurisdiction, employs halfway measures to deter flight, and requires the court to inform itself of the circumstances of each case.

The section establishes the boundaries of the court's discretion in setting the conditions for release. The court can restrict the freedom of the accused, but not deny such freedom altogether. These conditions provide adequate supervision of the accused because, unlike bail release, the accused can be required to maintain regular contact with the court or law enforcement agency, depending on the type of restrictions imposed by the court. ${ }^{\text {to }}$ Under the present system, if the accused

In any case where a financial deposit is required by the court, the amount required shall be ten percent of the amount set. If the amount of bail is so fixed, the accused may obtain his release by depositing the amount in the registry of the court in cash or other security, which shall be returned upon fulfillment of the conditions of release, less court costs. Such condition shall not be imposed where it appears that such financial obligation will impair the ability of the accused to prepare an adequate defense, and in no case be greater than the particular accused can pay.

This section is similar to the Illinois "ten percentum" release procedure except for the "ability to pay" and the "defense" limitations. The provision is not recommended; in most cases the limitations will preclude imposing bail at all, and where they do not, the accused will often be so affluent that the amount imposed will be no more than an "incentive" to appear.

Other reasons militate against the use of a financial provision. It would create a ground for detentiou based on inability to deposit the amount required by the court in a statutory system where the only ground for detention is intended to be willful nonappearance on the original charge, see proposed section 1276 infra. Furthermore, if judges using the condition followed traditional reasons for setting high but purportedly reasonable bail, the amount set would turn on the seriousness of the offense, see text accompanying note 30 supra. Fimally, judges familiar with the old bail system might rely on this provision to the exclusion of the other methods of release, inhibiting implementation of, and experimentation with, the other nonpecuniary alternatives. $C f$. Note, The Bail Reform Act of 1966, 53 Iowa L. REv. 170, 180 (1967) [hereinafter cited as Note, 1966 Bail Reform Act].

75. This section adopts, with a few changes, the provisional release procedure of the Federal Bail Reform Act, 18 U.S.C. $\$ \S 3146-52$ (Supp. IV, 1965-68). Section 3146 is the relevant section. There are no published studies that determine the default rate of accused released under the provisional release section of the Federal Bail Reform Act. See Note, Bail Reform in the State and Federal Systems, 20 VAND. L. REV. 948, 962 (1967).

76. An aceused released on bail in practice is always free to leave the jurisdietion, sincc bondsmen exercise little, if any, of their supervisory powers over the accnsed once he returns to the community. Comment, California Bail System, supra note 1, at 1160 . 
absconds, the court may not know of it until the day he is due for appearance. Under the provisional release procedure, the court knows immediately of the accused's flight by his failure to perform a specified condition.

The custody provision takes into account the lower rate of forfeiture of bond when an accused is released on bail raised by family or friends. ${ }^{77}$ The accused feels a greater obligation not to violate the trust he has made with the court when released to his family. ${ }^{78}$ Many accused have law-abiding relatives who are concerned over the arrest of a member of their family. If release to the family is thought to be inadequate, or the accused has no relative or friend willing to take responsibility, the court can designate an organization ${ }^{70}$ to take custody of the accused.

Where the court believes further restrictions are necessary, it can restrict the travel, association, or abode of the accused durimg the period of release or require him to return to custody after daylight hours. The court may also impose any combination of these restrictions.

The "other reasonable condition" provision affords a basis for the court to innovate, to develop a set of conditions designed to meet the needs of a particular case. However, the provisions are not designed to place unnecessary burdens on the accused. An accused living in a jurisdiction 50 miles away, and whose job keeps him at work until evening, should not be required to return to the jurisdiction of arrest

77. Foote, Philadelphia Bail Study, supra note 9, at 1062, 1064-65.

78. The Oakland Pre-Trial Release Project noted that the one community tie that its applicants did possess in some strength was a fairly constant association with other family members. OAK. REP., supra note 5 , at 50 .

79. E.g., the accused's employer, labor union, church, fraternal group, or community organization. An accused in need of medical or psychiatric treatment might be released to a hospital or public health facility. See Wald \& Freed, The Bail Reform Act of 1966: A Practitioner's Primer, 52 A.B.A.J. 940, 943 (1966) [hereinafter cited as Wald \& Freed]. In Connecticut, a league composed of thirteen colleges accepts custody of accused students under the Federal Bail Reform Act. Settlement houses in New York and some civil rights organizations are also assuring the accused's appearance. Id.

There are two criticisms of the proposed release provision. One is that an organization (or person) has no possibility of fimancial loss if the accused does not appear and therefore has no incentive to insure the accused's appearance. But financial loss, even in the bail system, does not guarantee adequate supervision. See note 76 supra. A second criticism is that a corporate entity or organization will not adequately supervise the accused while he is at liberty. A safeguard of the provisional release section is that the more distant the relationship or lack of concern for the accused's appearance at the required time, the more reluctant an organization will be to assume a supervisory obligation. Note, 1966 Bail Reform Act, supra note 75, at 170, 181 (1967). Furthermore, future ineligibility of an organization to take custody may serve as a sanction against inadequate supervision. The flexibility of the provisional release section allows the magistrate to consider the risk involved in releasing the accused to a particular organization and to choose a responsible one. 
at night if some other restriction or combination of restrictions will suffice.

The discretion of the court is considerably narrowed under proposed section 1274. The broad power to set "reasonable" bail in the bail system has a severely regressive effect on pretrial release. One may legitimately question this theoretical proscription against excessive baii $^{80}$ when a large number of accused spend the majority of their pretrial period in detention.

The provisional release procedure eliminates two problems that exist under the bail system with respect to the exercise of discretion. One is the incarceration of an accused because the judge lacks knowledge of the circumstances of his case necessary to set a bail amount that will insure his presence. ${ }^{81}$ The information on the accused is generally limited to his past record and the current charge. ${ }^{82}$ The amount of bail, therefore, is based only on these factors. The result of exclusive reliance on the nature of the offense charged and the past record as a guide to bail determination is that as the seriousness of the charge and the length of the record imcrease, the bail rises, notwithstanding the fact that the accused does not have the funds to make the bail set or that he would be a good risk if other factors were considered. Thus, while the trial judge, because of his presumed familiarity with the facts and financial ability of the accused to give security, is supposedly able to determine what would be reasonable bail, he is in many instances unaware of the financial ability of the accused to pay. An accused appealing the amount as excessive will find that the amount must be unreasonable and disproportionate to the offense charged ${ }^{83}$ before an appellate court will grant rehief. In order to invoke the provisions of section 1274 properly, the judge must know something about the cir-

80. Excessive bail is prohibited. CAL. Const. art. I, $\$ 6$.

81. But see CAL. PENAL CODE $\S 1318.1$ (West Supp. 1968), which empowers a court, with the concurrence of the board of supervisors, to employ a staff for the purpose of recommending whether an accused should be released on his own recognizance.

The proposed provisional release section requires the magistrate to be fully informed of the circumstances of the accused. Furthermore, the magistrate must inake a determination that there is convincing evidence that release on unconditional ownrecognizance will result in the willful nonappearance of the accused.

While the proposed provisional release section contemplates that the magistrate's decision in tailoring conditions will be based on a full range of background information, the information requirements are not intended to delay the release of the accused or hamper the efficiency of the court in other judicial matters. Because of time limitations, a busy magistrate should not have to spend more time than is reasonably necessary to gather information. See Note, 1966 Bail Reform Act, supra note 74, at 178. The requirements are, however, broader than those of the Federal Bail Reform Act, which allows conditions to be imposed on the basis of available evidence. 18 U.S.C. $\$ 3146$ (b) (Supp. IV, 1965-68).

82. See Ares, Rankin \& Sturz, Manhattan Bail Study, supra note 6, at 71.

83. Ex parte Duncan, 53 Cal. 410,411 (1879). 
cumstances of the accused besides his current charge and past record. ${ }^{84}$

A second deficiency of the present system is the use of bail as an instrument for continued mcarceration of the accused by setting it so high as to make it impossible for the accused to pay. This has been cited by some as an advantage of the present system, as it allows the trial judge to keep an accused in jail if he feels this is "necessary." But such a practice clearly contradicts the purpose of bail and invidiously discriminates against poor accused. These abuses can rarely be detected on appeal because they do not appear in the record. ${ }^{86}$ The provisional release section limits this possibility of abuse by limiting the options of the magistrate. A court cannot set conditions that will preclude release. Bail law offers the accused only two alternatives: total release or total mcarceration. Either an accused can buy his way out or he must remain in jail. The alternatives of section 1274 are halfway measures. The court, in its discretion, can provide for any quantum of contact it deems necessary to deter flight. This flexibility compels some individualization of release procedure by requiring the trial court to shape the form of release to fit the case. ${ }^{87}$

The emphasis of section 1274 is on preventing willful nonappearance rather than insuring the presence of the accused. The section

84. A magistrate must do considerably more than examine the charges against the accused and his prior record. He must draw upon the knowledge of the arresting officer, the accused, or his attorney. See Wald \& Freed, supra note 79 , at 942 . The attorney can be helpful to the court by formulating a release plan. Id.

In some cases, information about the accused may not be readily obtainable. If such circumstances arise, the magistrate originally imposing the conditions can amend the order of release upon obtaming information showing the reliability of the accused. The purpose of the amendment provision is to allow the magistrate to alter conditions where subsequent information reveals that he has over-estimated the risk of willful nonappearance. The accused may also appeal any condition imposed under proposed section 1275. Additional information gathered during the 24 hour period preceding appeal which indicates the reliability of the accused is grounds for the reviewing court to rescind or reduce the conditions imitially placed on the accused's release.

Verfication and evaluation of the information obtained by the court is not covered by the provisional release section. Verification could probably be accomplished by a clerk of the court or a specially appointed officer whose sole job is to verify information. See CaL. Penal Code $\S 1320$ (West Supp. 1968). Evaluation of the information is the responsibility of the magistrate presiding at the release hearing. He must decide what restrictions are suitable to the risk of nonappearance in a particular case. See Note, 1966 Bail Reform Act, supra note 74, at 179 (1967).

85. Note, New York Bail Study, supra note 46, at 705.

86. See Foote, Crisis in Bail, supra note 22, at 994 n.160.

87. See text accompanying note 32 supra. The inquiry provision makes mandatory the exercise of the fact-gathering powers of the court. Section 1274 can be utilized fairly and effectively only after an investigation of the circumstances of the accused. This requirement prevents the wholesale imposition of restrictions on accused persons. An investigation of the background of the accused will enable the court to tailor the restrictions to the particular case. The term "circunstances" in section 1274 uneans that any fact relevant to the probability of flight is open to the court for consideration. 
creates a bias in favor of release. Unless the court has convincing evidence that the accused will willfully fail to appear, it must release him. Thus it enables the accused without community ties to secure release if no showing can be made that he will intentionally fail to appear. The court no longer looks for reasons why the accused will appear but for reasons why he will not. The existence of convincing evidence of risk of nonappearance is a matter for the court to decide on the basis of all the circumstances of the case and the situation of the accused. Under current bail procedure, the accused is presumed to be a potential nonappearing misdemeanant or felon if he cannot post bail or has no ties to the community. The presuniption of the proposed statute is that the accused will appear unless there is evidence to the contrary. ${ }^{88}$

\$ 1275. Appeal from Provisional Release. A person detained twenty-four hours or who has any of the restrictions of section 1274 imposed upon his release, or who is detained pursuant to section 1277 or section 1280 , may appeal the order of the court.89

This appeal section allows any detained accused, including an accused who fled and has been apprehended, to appeal the grounds for his detention, ${ }^{90}$ and it affords the accused a speedy release where he is detained longer than is reasonably necessary, or where the court has unfairly burdened him with conditions. The court nust determine the appeal promptly because an important freedom is involved. Since detention for flight requires willfulness under this chapter, ${ }^{91}$ denying a defaulting accused a right of appeal might unfairly detain him if his failure to appear was non-willful. An appellate court will have available in writing the reasons given by the lower court for the imposition of conditions. This requirement should prevent abuses in the trial court froin escaping the scrutiny of the reviewing judge. ${ }^{92}$ The Legis-

88. It is impossible to state with precision just what evidence would justify a finding that an accused will flee. Certainly more is required than motivation to flee and the means to accomplish this purpose; any accused who beheves he may be convicted possesses this motivation and need only choose the mode of modern transportation by which it is most expedient to leave the jurisdiction. Foote, Crisis in Bail, supra note 22, at 1168. Each case will turn on facts and circumstanees too subtle to enumerate as clear-cnt rules. Evidence of prior flight, a prior pending charge which the accused has failed to answer, statements of the accused, or known plans to abscond would be relevant. In such cases, the court may impose the conditions enumerated.

89. A review of the initial setting of conditions must be sought by the accused. It is not autonatic. See 18 U.S.C. §§ 3146(d), 3147 (Supp. IV, 1965-68).

90. Unlike the Federal Bail Reform Act, which limits an appeal to an accused who is unable to meet the conditions of release or must return to custody after specified hours, section 1275 allows an accused to appeal any restriction iniposed upon him by the court. See 18 U.S.C. $\$ 3147$ (Supp. IV, 1965-68). Thus the accused can appeal a condition of release that he cannot fulfill without hardship.

91. See discussion of proposed section 1276 infra.

92. See text accompanying notes $85-86$ supra. 
lature recently added to the California own-recognizance release procedure a provision for automatic review of the order fixing the amount of bail if the accused is detained because of inability to post the amount fixed. ${ }^{93}$

§ 1276. Failure to Appear on A Felony Charge A Felony; Failure to Appear on A Misdemeanor Charge A Misdemeanor. Every person charged with a felony who willfully fails to appear is guilty of a felony. Every person charged with a misdemeanor who willfully fails to appear is guilty of a misdemeanor.

Section 1276 places primary responsibility on the accused for his appearance in court. "Willful" nonappearance requires an intent on the part of the accused not to appear for the purpose of avoiding prosecution. Section 1276 adopts sections 1319.4 and 1319.6 of the California Penal Code, which currently apply only to release on own recognizance, and extends their coverage to any release under this chapter. ${ }^{94}$ Presently, there is no comparable penalty for jumping bail.05

$\S 1277$. Imposition of Conditions Upon Nonappearance. If the arrested person fails to appear as required, the court may issue out a warrant of arrest. If the accused appears within forty-eight hours in person or by representative, and can show proof of good cause for his failure to appear, the court shall reinstate the arrested person on his own recognizance and may impose the conditions, or any combination thereof, of section 1274. A default within the provisions of section 1276 is grounds for detention, provided that the accused may not be detained for a period longer than that specified in section 1382 of the Penal Code. The court shall set forth in writing the reasons for its finding. A default not withm the provisions of section 1276 is not grounds for detention. Any person detained under this section may appeal the finding of the court pursuant to section 1275. Neither a finding by the trial court of willful nonappearance nor an affirmance of such finding by a reviewing court shall be admissible in an action brought by the State against the arrested person for willful nonappearance under section 1276 of the Penal Code. This provision is not to be deemed exclusive of any other remedies of the arrested person.

Section 1277, in conjunction with section 1276 , sets out the consequences that follow from the accused's failure to appear, whether for willful or technical reasons. These sections protect an accused released provisionally or otherwise who fails to appear on technical grounds,

93. Cal. Penal Code $\$ 1320$ (West Supp. 1968). The review must be made not later than five days from the time of the original order. Id. A person detained before trial because of mability to make bail or insufficient ties to the community may seek a writ of habeas corpus. CAL. PENAL CoDE $\$ \S 1490-91$ (West 1957).

94. California bail law distinguishes between willful and non-willful appearance. Cax. Penal Code $\S 1305$ (West Supp. 1968); id. $\S \S 1319.4$, 1319.6.

95. Comment, California Bail System, supra note 1, at 1152. 
make a finding of willful nonappearance inadmissible in a section 1276 prosecution for flight, and provide the accused with an effective, although not exclusive, remedy for detention or conditional release.

Once the accused has failed to appear, a subsequent appearance within 48 hours and good explanation for his nonappearance requires the court to release him with or without conditions imposed. ${ }^{96}$ If the court does not accept the explanation, it may, subject to section 1382 of the Penal Code, ${ }^{97}$ order the accused detained until a trial date has been set. The accused may appeal this finding under section 1275. An accused who appears after the 48-hour period and can show good cause for his nonappearance may be released. However, the court may order detention and thus require the accused to appeal.

The inadmissibility in a section 1276 penalty trial of a finding of willful nonappearance prevents the use of a finding of fact in a nonadversary proceeding from being used in an adversary proceeding. The final provision makes certain that the statute is not construed to be the sole remedy of the accused. The detained arrestee can utilize any traditional method of securing release. ${ }^{98}$

\& 1278. Breach of Agreement. If the accused fails to comply with any of the conditions imposed upon him by the court, further conditions or any combination thereof may be imposed. Failure to comply is not grounds for detention. Willful failure to comply is a misdemeanor, regardless of the outcome of the original charge. A finding by the trial court of willful breach of agreement under this section shall not be admissible in an action brought by the State against the accused.

In the saine manner that section 1277 distinguishes between the

96. Compare with proposed section 1277 CaL. Penal CODE $\$ 1305$ (West Supp. 1968): "Upon the accused's nonappearance without sufficient excuse when his presence in court is required, at any time within 180 days, if the accused and his bondsman appear and offer au excuse or proof of nonconnivance, or if the bondsman appears and offers an excuse to the court's satisfaction, the court inust remit the forfeiture upon such teruns as may be just. The forfeiture may be set aside if the bondsman appears in court with the accused in his custody within the 180 day period, and noves to set aside the forfeiture, surrenders the accused to the court, or requests the court not to reinstate the bond."

97. CaI. Penal CODE $\S 1382$ (West Supp. 1968) prevents the possibility of the accused remaining in jail for an excessive period of time before the adjudication of his case. A court must dismiss an action where, inter alia, the accnsed is not brought to trial in a superior court within 60 days after the finding of an indictment or information; or in a misdemeanor case regardless of when the complaimt is filed, if the accused is not brought to trial within 30 days after he is arraigned if he is in custody at the time of arraignment; or in all other cases, within 45 days after his arraignment.

In order to make the language of section 1382 consistent with that of proposed section 1277, and to effectuate the policy of the proposed pretrial release statute against unnecessary detention, it is recommended that section 1382 be amended to make the limitation periods run from the date of the court's order of detention.

98. E.g., CAL. PeNaL CODE $\$ \S 1490-91$ (West 1957) (habeas corpus). 
"willfully" defaulting accused and the "technically" defaulting accused, section 1278 distinguishes between the "willfully" breaching accused and the "technically" breaching accused. Some breaches may be technical, and the accused who makes a mistake should not be punished in the same manner as an accused who intentionally breaches a condition.

In either case, the accused can only be guilty of breach of agreenient. The accused may appear before the court and explain his noncompliance. The reasonableness of his explanation will, to some extent, depend on the number and type of limitations, if any, miposed on him under section 1274. It is improbable that an accused would "forget" to call an officer of the court; it would not be unlikely for an accused to miss a night at a detention center if he were ill or had been involved in a traffic accident. Adequate penalty is provided for willful noncompliance. If an accused can be imcarcerated only upon a finding of willful nonappearance, breach of condition alone should not be a sufficient ground for incarceration. The madmissibility in a section 1278 penalty trial of a finding of willful breach by the accused prevents the use of a finding of fact in a nonadversary proceeding from being used in an adversary proceeding.

§ 1279. Instructions to the Accused. Upon release the court shall inform the accused of the penalties for noncompliance with this article orally and in writing in the Englishr language and, if necessary, in the language with which the accused is familiar. ${ }^{99}$

The court must inform the accused of any condition imposed on his release and the penalty for breach of condition and for nonappearance. If these penalties are to have any deterrent value, the accused must be informed of the sanctions. Failure to instruct in the case of nonappearance might prevent conviction in an action brought by the State under section 1276, but would not prevent detention under section 1277. Failure to instruct might be considered prejudicial in a criminal proceeding. However, the willfully defaulting accused should not be able to take advantage of an error of the court to facilitate a subsequent effort to abscond. Here the purpose of the article would be violated.

The requirement to imstruct the accused orally and in writing in a language with which he is familiar is desigued to assure full understanding of the penalties for noncompliance by all persons before the court. The fact that niany accused are illiterate or have inadequate command of the English language necessitates this requirement. ${ }^{100}$

$\S 1280$. Release After Conviction. If the judgment imposes a fine,

99. Proposed section 1279 incorporates in part 18 U.S.C. \& 3146(c) (Supp. IV, 1965-68).

100. Ares, Rankin \& Sturz, Manhattan Bail Stucly, supra note 6, at 75. A court located in San Francisco, for example, would distribute instructions to the accused in English, Chinese, or Spanish. 
or imprisonment in the case of a misdemeanor, the convicted person awaiting appeal shall be released. The court may impose the conditions of section 1274 or any combination thereof. A person convicted of any other offense may be treated in the same manner. If the court believes that no one or more conditions of release in section 1274 will reasonably assure that such convicted person will not willfully default, or if it appears that an appeal is frivolous, ${ }^{101}$ sucl convicted person may be ordered detained. The court may require a person convicted of a felony whose sentence is other than a fine to produce evidence in favor of release. The judge shall set forth the reasons for detention in writing pursuant to section 1274. The convicted person may appeal the decision of the court under section 1275. This provision is not to be deemed exclusive of the remedies $^{\mathbf{1 0 2}}$ of the convicted person.

This post-conviction provision affords release to all accused irrespective of the nature of the judgment. If the judgment is a fine, or in the case of a misdemeanor, if the judgment is imprisonment, the accused has an absolute right to release. ${ }^{103}$ Felons who receive a

101. See 18 U.S.C. § 3148 (Supp. IV, 1965-68).

102. See note 98 supra.

103. Compare this provision with CaL. Penal Code $\S 1272$ (West 1957). California bail law has always made two exceptions to the absolute right of bail: Capital offenders, where the proof of their crime is evident or the presumption thereof is great, are not bailable, presnmably because the accused will flee (see note 61 supra); convicted felons whose judgment is not a fime have no absolute right to bail because upon conviction, they lose the benefit of the presumption of innocence, and are presumed guilty. Article I, section six of the California Constitution provides that "All persons are bailable by snfficient sureties unless for capital offenses when proof is evident or the presumption great ...." However, this provision has been construed to entitle a party to bail as a matter of right only in those cases where he has not already been convicted. The broader interpretation, which would imclude offenses before and after conviction not punishable by death, has been rejected. Ex parte Voll, $41 \mathrm{Cal}$. 29, 32 (1871) (so far as cases after conviction were concerned, the provisions of the 1849 Constitution that "All persons shall be bailable . . . unless for capital offenses when the proof is evident or the presumption great" was not intended to alter the comnon law rule that applications for bail on appeal were addressed to the discretion of the court); Ex parte Hoge, 48 Cal. 3, 6-7 (1874) (judicial discretion should be exercised in favor of granting bail ou appeal, since the accnsed should not be made to suffer detention which the constitutional riglit of appeal was designed to prevent); $E x$ parte Brown, 68 Cal. 176, 8 P. 829 (1885) (reaching the same result as Ex parte Voll, supra, with respect to the bail provision as incorporated without change in language im article I, section six of the 1879 California Constitution). The release of these two classes of accused is in the discretion of the court, and, therefore, the court may consider other factors in determining the propriety of release. See note 7 supra.

The distinction between bail before and after conviction is rooted in the legislative and judicial history of California. Prior to 1872, the California courts had no authority to stay proceedings upon appeal takeu from judgments in felony cases less than capital in degree. Ex parte Hoge, supra; Ex parte Marks, 49 Cal. 681 (1875). The only method by which a stay could be effected was by admitting the prisoner to bail under section 1272. Id. Bail pending an appeal, therefore, was exercised with great liberality. Id. Section 1243 of the Penal Code, enacted in 1872, stayed execution of judg- 
sentence of imprisonment or death may be ordered detained. The court may require such a felon who requests release to produce evidence indicating that he will not intentionally default.

The proposed post-conviction section does not substantially alter existing law which affords the right of release to all accused awaiting appeal, except in felony cases where the judgment is not a fine. ${ }^{104}$ Felons may be released in the discretion of the court under current law and under the proposed section. ${ }^{105}$

The proposed post-conviction section places the burden of producing evidence on certain convicted felons because the balance between the interests of the accused and the interests of society shift upon conviction of the accused. The presumably innocent accused at the pretrial stage has been adjudicated guilty, and the interest of society in protecting its members and institutions becomes paramount. However, because on appeal the accused may be found innocent or entitled to a new trial, he should be able to present to the court meritorious grounds for release. Judicial power to deny release unless the convicted accused produces evidence that he will not willfully default provides protection for society and effectuates both present California policy ${ }^{100}$ and that of the proposed statute that trial and appellate courts should exercise their discretion in favor of granting release.

The accused detained while awaiting appeal can request the judge originally imposing the detention to amend the order or he can appeal under section 1275. The judge who finds that a risk of willful non-

\footnotetext{
ment by appeal in all capital cases, and in all other cases where the judge in whose court the accused was convicted certified there was probable cause for appeal. CAt. Penal CODE $\$ 1243$ (1872). In Ex parte Marks, supra, the California supreme court reasoned that since the accused was not protected by section 1243 , he should not be released pending appeal under section 1272 unless an "extraordinary circumstance" intervened between the verdict of the jury and the appeal. Id. at 683. The extraordinary circumstances test remained the guiding criterion for the exercise of discretion in bail cases pending appeal until In re Brumback, 46 Cal. 2d 810, 299 P.2d 217 (1956), when the California supreme court substantially modified it. See Ex parte Smallman, 54 Cal. 35 (1879); Ex parte Brown, 68 Cal. 176, 8 P. 829 (1885); Ex parte Smith, 89 Cal. 79, 26 P. 638 (1891); Ex parte Turner, 112 Cal. 627, 45 P. 571 (1896) (a convicted accused inust make an affirmative showing of some extraordinary circumstance before the court has abused its discretion in denying bail on appeal); In re Pantages, 209 Cal. 535, 291 P. 831 (1930). In Brumback the court held that the test enlarges rather than restricts the permissible discretion of the judge under section 1272, that the trial court can grant bail on appeal even though an extraordinary circumstance has not occurred, and the primary purpose of bail, before and after appeal, is to insure the presence of the accused in court when required. In the case of appeal upon conviction, release on bail is in the discretion of the court, which allows the judge to consider other factors in deciding whether or not to release the accused on bail.

104. See CaL. Penal Code $\$ 1272$ (West 1957).

105. Id.

106. Molinari, Bail Pending Appeal in California, 1 U. SAN Fruncisco L. REv,, 217, 221 (1967).
} 
appearance exists must give reasons for his findings in writing as provided by section 1274. If the accused is denied both amendinent to, and appeal from, the order for detention, he can pursue any other traditional remedy he may have for release on appeal. ${ }^{107}$

$\S 1281$. Effect of Article on Other Statutes: Limitation. The provisions of this article shall not be construed to apply to sections 701-14 of the California Penal Code or Division VI of the California Welfare and Institutions Code.

The two provisions exempted from the operation of this proposed statute serve purposes different from those of pretrial release. Sections 701-14 of the California Penal Code are provisions for security to keep the peace. Upon a showing that the arrested person threatened to commit an offense against the person or property of another, the magistrate can require the arrested person to post a bond not to exceed 5,000 dollars for six months, or commit the arrested person to jail until the amount is posted. Division VI of the California Welfare and Institutions Code provides for the civil commitment of the mentally ill.

\section{CONCLUSION}

This Comment has discussed the erroneous assumptions underlymg current California bail procedure in order to show that the state interest would not be endangered by releasing most accused before trial without bail or without meeting the present own-recognizance requirements. A pretrial release statute has been proposed, the purpose of which is to release as many arrestees as possible while imsuring that almost all will return. The proposed statute draws upon the fornis of pretrial release other than bail now in use im the Umited States and extends the California citation and station-house release procedures to misdemeanor and felony arrestees. The system is designed to permit flexibility by local magistrates in adapting the type of release best suited to a particular offense.

The implementation of the proposed pretrial release statute could be acconiplished by establishing a pilot prograin in a small town or judicial area. If successful, the procedure could be extended, on an experimental basis, to an entire county, or to an urban area. The use of the statute in a large city would allow local judges to ascertain its effectiveness with virtually every type of offense.

The proposed statute considers both the interests of the accused and society and attempts to strike a fair balance between them. These two interests are balanced in a manner that does not protect the interests of one side to the exclusion of the interests of the other.

Dan Lang

107. See In re Brumback, 46 Cal. 2 d 810, 299 P.2d 217 (1956) (habeas corpus). 